\title{
Burton Mack's Myth of Innocence as Can(n)on Criticism
}

\author{
A Review of: \\ Mack, Burton L. A Myth of Innocence: \\ Mark and Christian Origins. Philadelphia: Fortress Press, 1988. \\ GREG WOOLVERTON \\ 3rd Year, BA Honours History \\ University of Alberta \\ Edmonton, Alberta
}

Burton Mack's Myth of Innocence may be seen as canon criticism. The book contests the function of the narrative gospel of Mark as a charter document for contemporary American self-identity. Mack deploys a noncanonical reading strategy of rhetorical analysis and narratological criticism in order to dislodge the text from its canonical status and function. ${ }^{1}$ The resistance of Mark's gospel to its function as the American myth of innocence is found in its distance from the earliest Jesus movements and texts. Once uncovered that distance makes clear the nature of Mark's ideological manipulation of his sources, which undermines the plausibility of the Jesus story told in the gospel. The real events of the gospel are not the story told but the social formation of objects that leave their trace on the text. Mack's plan "[...] is simply to position Mark within the social and textual histories of the several early Jesus movement, determine the changes he

\footnotetext{
${ }^{1}$ Dominick LaCapra, History, Theory, Trauma: Representing the Holocaust (Ithaca: Cornell University Press, 1994), 19-39.
} 
introduced in the writing of the gospel, and then assess his accomplishment and its legacy." ${ }^{2}$

Mack's reading initiates credibility tests of the gospel story as told. ${ }^{3}$ Too many heterogeneous Jesus-objects can be shown to have emerged simultaneously from the surfaces of primary/secondary associations among people (Jesus movements in the plural); authority figures (Mark himself as author, et al.); and grids of specification (hermeneutics and traditions) for them to have "originated" as a response to the person of Jesus himself. To Mack, Mark's narrative is no longer a text worth thinking-with in a manner that occults the reproduction of ideology uncritically. Rather, Mack accounts for the text's gaps, its nonadherence to its own narrative in order to stave-off the possibility of an applicable referential hermeneutic, one that would interpret the narrative as actual and therefore normative.

Mack's method accounts for the un-likeliness of the story once incredulity is proposed. Based on an initial binary opposition between status and power that contains the social fragmentation of first-century Palestine, Mack proposes the sociogenesis of the gospel as the result of people "picking up the pieces" as it

\footnotetext{
${ }^{2}$ Mack, Burton L. Mark and Christian Origins: A Myth of Innocence (Philadelphia: Fortress Press, 1988), 12.

${ }^{3}$ Marc Bloch, The Historian's Craft (New York: Alfred A. Knopf, 1961); Bloch offers only a few "scientific" tests for credibility: non-contradiction, the psychology of evidence, and the psychology of criticism. Mack relies on the psychology of criticism: an assessment of author/redactor's motives based on the likelihood of the story told. In Bloch the "likelihood" of the story is left hanging between these scientific determinants and questions of reflective judgement, hence history's ambivalent status as science and art. I am merely suggesting that Mack be located in a general epistemological relation to Annales within a disciplinary matrix of historical schools with common epistemological and methodological concerns.
} 
were. Prising constituent discursive unities of Mark's gospel apart and relating these to disparate social formations opens a space of myth between the circumscribed discursive unity and the daily round of Hellenistic Palestine. Mack's moves here are similar to Bruce Lincoln's theory of myth.

But if we are to treat myth as an ideological and not simply a taxonomic discourse, we will need a more dialectic, eminently political theory of narration, one that recognizes the capacity of narrator to modify details of the stories that pass through them, introducing changes in the classificatory order as they do so, most often in ways that reflect their subject position and advance their interests. ${ }^{4}$

Myth is ideology in narrative form for both Lincoln and Mack.

Competitive discourses ${ }^{5}$ are apparent once mythic space is opened out

onto the social. ${ }^{6}$ Based on Foucault's Archaeology of Knowledge, Mack perceives

the space of myth as a new mode of exclusion and the formation of a new object

in discourse, namely, the identity of the Markan group in Syria at odds with the

synagogue.

Mark's gospel was not the product of divine revelation. It was not a pious transmission of revered tradition. It was composed at a desk in a scholar's study lined with texts and open to discourse with other intellectuals $[\ldots]$ The story was a new myth of origins. A brilliant appearance of the man of power, destroyed by

\footnotetext{
${ }^{4}$ Bruce Lincoln, Theorizing Myth: Narrative, Ideology, and Scholarship (Chicago and London, University of Chicago Press, 1999), 149.

5 Michel Foucault, The Archaeology of Knowledge (Trans. Sheridan A.M. Smith; London and New York: Routledge, 2002). It's hard to know how to cite Foucault anymore since the text is woven into my own parlance. I rely explicitly on the analytics outlined in that book just as Mack relies on Foucault for the construction of method.

${ }^{6}$ Jacques Derrida, "Differánce," in Margins of Philosophy (Trans. Alan Bass; Chicago: University of Chicago Press, 1982), 13; linguistic space is analogous to the space between the order of signification and the daily round; cf. Burton Mack, "Social Formation," in W. Braun and R.T. McCutcheon (eds.), Guide to the Study of Religion (London: Cassell, 2000), 289-90; "Two of the more obvious characteristics of myths and rituals are the ways in which they focus attention upon symbols and images in orders of time and space at a distance removed from the everyday world of activity, and exaggerate the descriptions of the figures and activities that inhabit and configure those imaginary worlds."
} 
those in league against God, pointed nonetheless to a final victory when those who knew the secret of his kingdom would be finally vindicated for accepting his authority. ${ }^{7}$

In composing the myth, Mark constituted an identity for his group ruled by a network of relations at once historical, social, and political. These relations rule the formation of texts and objects as their conditions of possibility. Relations are not present in the object but as the conditions of possibility they exteriorize an object in a field of discourse. ${ }^{8}$

Mack's reading strategy also relies on a rhetorical analysis of the texts constitutive for the gospel of Mark. There is a parity of form and purpose between Mark and Hellenistic literature that foregrounds not what the text means but what the text does. It persuades, mediates, and defines. Mack's method here resonates with Frederic Jameson's discussion in The Political Unconscious: history is not re-presented in the text, rather the text itself is an historical event and the real is only accessed through its prior textualization and narrativization. The task of the scholar is mediation, establishing the relation between a text and its social ground. "[T]he individual narrative, or the individual formal structure, is to be grasped as the imaginary resolution of a real contradiction." ${ }^{9}$ Thus for Mack, the constitutive components of the text have their origin in contestatory experiences of the social.

The methodological assumptions of a rhetorical analysis lead to Mack's examination of the gospel's narrative content. There is a recursive logic of

\footnotetext{
${ }^{7}$ Mack, Myth of Innocence, 322-23.

${ }^{8}$ Foucault, Archaeology of Knowledge, 44-54.

${ }^{9}$ Frederic Jameson, The Political Unconscious: Narrative as a Socially Symbolic Act (Ithaca, NY: Cornell University Press, 1981), 77.
} 
emplotment operative in Mark from the level of the parable to the entire gospel story. Fundamental to the development and deployment of this narrative is the interpretation of events. If structured social formations begin the process of discerning meaning in the conflicts that complicate and drive social life, then it is the writer/redactor within networks of relations in society who engages in interpretation under the aegis of these political exigencies, crafting the narrative emplotment of their socio-genetic literary objects. Interpretation presupposes politics. $^{10}$

A model of discipleship grounds the agency of human actors in this drama of social formation. Jesus is an ironic model to be desired and imitated by disciples within the paradigm of obligations chartered in Mark's gospel. This model of discipleship is what anchors the socio-genesis of objects to the individual agents who operate in social formation. The gospel as paradigm, then, is a semiological text, ${ }^{11}$ a social praxis and order of signification that can be read, analysed, and made to speak in the same way that the linguistic/philological text of the gospel can be made to show forth its constituent parts and rhetorical function. Thus, the gospel is a communal framework, a regulatory fiction that mediates the boundaries of group identity as well as the hierarchical ranking of disciples within the group based on their desire for and emulation of the model

\footnotetext{
${ }^{10}$ Hayden White, The Content of the Form: Narrative Discourse and Historical Representation (Baltimore: John Hopkins University Press, 1987), 58-82.

${ }_{11}$ John Mowitt, Text: The Genealogy of an Antidisciplinary Object (Post-Contemporary Interventions; Durham: Duke University Press, 1992), 15.
} 
Jesus, who as model is himself constituted in the disciples' prior subjection of themselves to the communal framework. ${ }^{12}$

Mack's analysis of this model has a narrative structure of its own. "The shifts in attitude can be described as the sequence from an early period of optimistic activity, through a period of tussle and setback, to a later period of polemic and compensatory reaction." ${ }^{13}$ This is a tragic emplotment of the events which led to the composition of Mark and it is a proleptic moment in Mack's methodology. It foreshadows the tragic narrative of Mark's legacy through the European Middle Ages and contemporary America: a litany of bloodshed and horror matched only by the gospel's own apocalyptic vision of vindication and retribution. Mack's impulse here is reflected in the work of other scholars of religion and terror. ${ }^{14}$ Further, his use of history as a contemporary reversal and intervention ${ }^{15}$ has enormous precedent in other fields of historical inquiry. ${ }^{16}$

\footnotetext{
${ }^{12}$ Mowitt, Text, 23-47.

${ }^{13}$ Mack, Myth, 125.

${ }^{14}$ Mark Juergensmeyer, Terror in the Mind of God: The Global Rise of Religious Violence (Berkeley: University of California Press, 2000).

15 Jacques Derrida, "Outwork, Prefacing in Dissemination," in M. Drolet (ed.), The Postmodernism Reader: Foundational Texts (London ad New York: Routledge, 2004), 147-153.

${ }^{16}$ Interventions into the field of contemporary American millenialism abound in studies of medieval eschatology, cf., Caroline Walker Bynum and Paul Freedman (eds.), Last Things: Death and the Apocalypse in the Middle Ages (Philadelphia: University of Pennsylvania Press, 2000); interventions into a contemporary discourse on sexuality also, cf., Mark D. Jordan, The Invention of Sodomy in Christian Theology (Chicago: The University of Chicago Press, 1997) and Glenn Burger and Steven F. Kruger (eds.), Queering the Middle Ages (Medieval Cultures 27; Minneapolis: University of Minnesota Press, 2001). The common thread here is scholarship as intervention, as canon criticism that dislodges accepted primary and secondary texts from their place in an ideological construct constituted in and constitutive for social formations in contemporary life.
} 
Mack wants to replace messianism with messianicity. "This would be the opening to the future or to the coming of the other as the advent of justice, but without horizon of expectation and without prophetic prefiguration." ${ }^{17}$ Messianism here is the following of a determinative framework into an unknown future, a framework that structures the pre-understanding of the future in such a way as to foreclose unknown possibilities in the interest of safety by predetermining the experience of unfolding time. Messianicity on the other hand is the desire and expectation of justice that nonetheless remains open to the radical possibilities of evil in order to maintain a universalizable - hence plural "culture of faith" and "foundation of law." Mack's gesture is bi-directional. He reaches back toward the historical Jesus as Cynic commentator and towards the future hope of social harmony.

\footnotetext{
${ }^{17}$ Jacques Derrida, "Faith and Knowledge: the Two Sources of 'Religion' at the Limits of Reason Alone," in G. Anidjar (ed.), Acts of Religion (New York: Routledge, 2002), 56.
} 


\section{Bibliography}

Bloch, Marc. The Historian's Craft. New York: Alfred A. Knopf, 1961.

Burger, Glenn and Kruger, Steven F. (eds). Queering the Middle Ages. Medieval Cultures 27. Minneapolis: University of Minnesota Press, 2001.

Derrida, Jacques. "Differánce." In Margins of Philosophy. Trans. Alan Bass. Chicago: University of Chicago Press, 1982.

Derrida, Jacques. "Faith and Knowledge: the Two Sources of 'Religion' at the Limits of Reason

Alone." In Gil Anidjar (ed.), Acts of Religion. New York: Routledge, 2002: 40-101.

Derrida, Jacques. "Outwork, Prefacing in Dissemination." In Michael Drolet (ed.), The Postmodernism Reader Foundational Texts. London ad New York: Routledge, 2004.

Foucault, Michel. The Archaeology of Knowledge. Trans. Sheridan A.M. Smith. London and New York: Routledge, 2002.

Lincoln, Bruce. Theorizing Myth: Narrative, Ideology, and Scholarship. Chicago and London, University of Chicago Press, 1999.

Mack, Burton L. Mark and Christian Origins: A Myth of Innocence. Philadelphia: Fortress Press, 1988.

Mack, Burton L. "Social Formation." In Willi Braun and Russell T. McCutcheon (eds.), Guide to the Study of Religion. London: Cassell, 2000: 283-96.

Mowitt, John. Text: The Genealogy of an Antidisciplinary Object. PostContemporary Interventions. Durham: Duke University Press, 1992.

Jameson Frederic, The Political Unconscious: Narrative as a Socially Symbolic Act. Ithaca, NY: Cornell University Press, 1981.

Jordan, Mark D. The Invention of Sodomy in Christian Theology. Chicago: The University of Chicago Press, 1997.

Juergensmeyer, Mark. Terror in the Mind of God: The Global Rise of Religious Violence. Berkeley: University of California Press, 2000. 
LaCapra, Dominick. History, Theory, Trauma: Representing the Holocaust. Ithaca: Cornell University Press, 1994.

Walker-Bynum, Caroline and Freedman, Paul (eds.). Last Things: Death and the Apocalypse in the Middle Ages. Philadelphia: University of Pennsylvania Press, 2000.

White Hayden, The Content of the Form: Narrative Discourse and Historical Representation. Baltimore: John Hopkins University Press, 1987. 